\title{
坐剤によるレボチロキシン投与が有効であった粘液水腫性昏 睡の1例
}

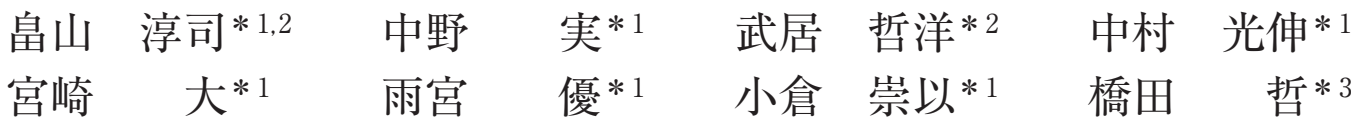 \\ *1 前橋赤十字病院高度救命救急センター集中治療科 ・ 救急科, $* 3$ 糖尿病 - 内分泌内科 \\ （ テ 371-0014 群馬県前橋市朝日町3-21-36） \\ *2 横浜市立みなと赤十字病院集中治療部 ( ₹ 231-8682 神奈川県横浜市中区新山下 3-12-1)
}

Key words: (1) myxedema, (2) hypothyroidism, (3) suppository

\section{はじめに}

粘液水腫性昏睡は稀な疾患で，早急に甲状腺ホルモ ンを補充しなければ多臓器障害に陥り致死的になり得 る。その死亡率は, たとえ集学的治療を行っても20〜 $25 \%$ とされ ${ }^{1)}$, 治療としてコンセンサスの得られたホル モン補充療法はない1),2)。今回我々は, 粘液水腫性昏睡 に対して合成サイロキシン（thyroxine，T4）製剤である レボチロキシンを坐剤で投与し，有効であった症例を 経験したため報告する。

\section{症 例}

患者：86歳, 男性。

既往歴：高血圧症，気管支喘息，胃潰瘍，前立腺癌。 現病歴：当院に入院する半年前から両側下腿に浮腫 を認めだし, 近医で利尿薬の処方を受けていた。1カ月 前から, 下腿浮腫の増悪, 労作時呼吸困難を認めた。入 院当日, 昏睡状態の患者を息子が発見し，当院に救急搬 送された。

来院時現症：意識レベル Glasgow coma scale $\mathrm{E} 1 \mathrm{~V} 1 \mathrm{M} 1$, 血圧 $113 / 74 \mathrm{mmHg}$, 脈拍 $57 / \mathrm{min}$ の心房細 動, 呼吸数 $6 / \mathrm{min}, \mathrm{SpO}_{2} 100 \%$ (酸素 $10 \mathrm{l} / \mathrm{min}$, バッグ バルブマスクによる補助換気), 体温 $33.9^{\circ} \mathrm{C}$ 。顔面浮腫, 巨舌を認め, 体幹・四肢に nonpitting edemaを認めた。

入院時検査所見：血液検査では, 肝逸脱酵素の上昇 (AST $289 \mathrm{U} / l$, ALT $108 \mathrm{U} / l)$, 高CK血症 $(3,709 \mathrm{U} / l)$,
低血糖 $(16 \mathrm{mg} / \mathrm{d} l)$ を認め, 甲状腺刺激ホルモン (thyroid stimulating hormone, TSH) $35.0 \mu \mathrm{IU} / \mathrm{ml}$, 遊 離トリヨードサイロニン (free triiodothyronine, FT3) $1.2 \mathrm{pg} / \mathrm{m} l$, 遊離サイロキシン (free thyroxine, FT4) $0.70 \mathrm{ng} / \mathrm{d} l$ と甲状腺機能低下を認めた。酸素 $10 \mathrm{l} / \mathrm{min}$ 補助換気下での動脈血ガス分析では, $\mathrm{pH} 7.37, \mathrm{PaCO}_{2}$ $50 \mathrm{mmHg}, \mathrm{PaO}_{2} 517 \mathrm{mmHg}, \mathrm{HCO}_{3}-28 \mathrm{mmol} / l$ と呼吸 性アシドーシスを認めた。頭部 CTや頭部MRIで，意 識障害の原因となる頭蓋内病変を認めなかった。心臓 超音波検査で，びまん性左室壁運動低下と全周性の心 囊液貯留を認めた。

臨床経過 (Fig. 1)：徐呼吸と意識障害のため, 救急外 来で緊急気管抻管を施行した。低血糖に対してブドウ 糖の補充を行ったが, 意識レベルの改善を認めなかっ た。甲状腺機能低下, 低体温, 低血糖, 特異的な身体所 見より, 意識障害の原因として粘液水腫性昏睡を疑い ICUに入室となった。ICU入室時のAcute Physiology and Chronic Evaluation (APACHE) II スコアは25点で あり, Sequential Organ Failure Assessment (SOFA) スコアは 8 点であった。なお, 既往の前立腺癌は, ホル モン療法によりコントロール良好であり, 今回の意識 障害の原因とは考えにくかった。

粘液水腫性昏睡に対しヒドロコルチゾン $300 \mathrm{mg} /$ dayの点滴静注後, レボチロキシン $12.5 \mu \mathrm{g}$ を胃管より 投与した。第 2 病日には $36^{\circ} \mathrm{C}$ 台まで復温され，血糖值 や循環動態も安定したが, E1V1M1の深昏睡が持続し

A case of myxedema coma successfully treated with levothyroxine in suppository form

Junji Hatakeyama*1,2, Minoru Nakano*1, Tetsuhiro Takei*2, Mitsunobu Nakamura*1, Dai Miyazaki*1, Yu Amemiya*1, Takayuki Ogura*1, Tetsu Hashida*3

${ }^{* 1}$ Department of Advanced Medical Emergency and Critical Care Center, ${ }^{*} 3$ Department of Diabetes and Endocrinology, Japanese Red Cross Maebashi Hospital (3-21-36 Asahi-cho, Maebashi, Gunma 371-0014, Japan), *2 Department of Emergency and Critical Care Medicine, Yokohama City Minato Red Cross Hospital (3-12-1 Shin-Yamashita, Naka-ku, Yokohama, Kanagawa 231-8682, Japan) 


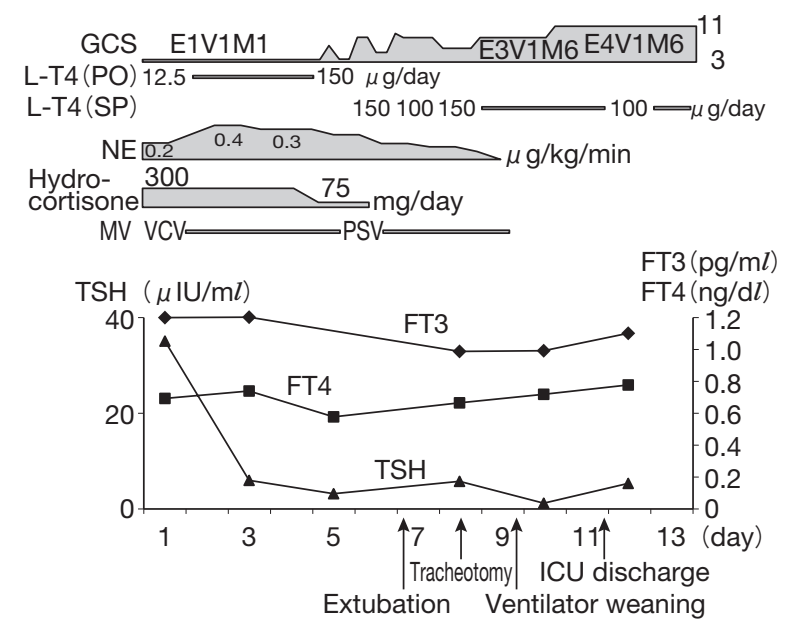

Fig. 1 Clinical course in the ICU

FT3, free triiodothyronine; FT4, free thyroxine; GCS, Glasgow coma scale; L-T4, levothyroxine; MV, mechanical ventilation; NE, norepinephrine; PO, peroral; PSV, pressure support ventilation; SP, suppository; TSH, thyroid stimulating hormone; $\mathrm{VCV}$, volume control ventilation.

た。レボチロキシンの投与量不足と考え, 第5 病日に $150 \mu \mathrm{g} / \mathrm{day}$ を経胃管投与したところ, 約 4 時間後に2 時間程度意識は E3V1M1 まで改善した。腸蠕動音低下 と単純 X線写真で腸管ガスの著明な貯留を認めたこと より, 腸管からの薬剤吸収低下の可能性も考慮し, 第6 病日に家族の同意を得てレボチロキシン $150 \mu \mathrm{g} / \mathrm{day}$ の坐剤を薬剤部にて作製し投与した。作製方法は，錠 剂を粉砕後, 100 メッシュのふるいを通し, 融解したホ スコ ${ }^{\circledR} \mathrm{E}-75$ (丸石製薬)，ホスコ ${ }^{\circledR} \mathrm{H}-15$ (丸石製薬) と混 合擋拌後, 坐剂コンテナに分注した ${ }^{3)}$ 。投与約 1 時間後 に意識がE4V1M6まで改善し，約 10 時間持続した。翌 日も $150 \mu \mathrm{g} / \mathrm{day}$ のレボチロキシン坐剂投与により, 意 識の更なる改善を認めたため抜管した。しかし, 痰の 喀出困難による上気道閉塞をきたしたため, 第 8 病日に 気管切開術を施行し, 第 9 病日に人工呼吸器を離脱し た。レボチロキシン坐剤 $150 \mu \mathrm{g} /$ day 投与を継続し, 痰 の喀出が良好となった第 11 病日にICUを退室した。第 22 病日, 坐剤から内服薬に変更し, 第59病日に転院と なった。今回の粘液水腫性昏睡の原因は, 抗甲状腺抗 体陰性等より特発性と診断した。

\section{考察}

粘液水腫性昏睡の基本治療が甲状腺ホルモンの補充 であることに異論はないが, 投与すべき甲状腺ホルモ ンの種類, 投与量や投与経路に関しては明確な治療指 針が確立されていない1),2)。特に投与経路に関しては, 本邦では合成甲状腺ホルモンの静注製剤が市販されて おらず，経胃管投与するしか現実的な方法がない。と ころが, 本症例の様に腸管蠕動運動が抑制されている 場合も稀ではなく, またT4製剤の経口投与による生物 学的利用能は約 $50 \%$ とされるため4), 投与効果の予測
は難しい。

我々の調べた限り,これまでに粘液水腫性昏睡に対 し甲状腺ホルモンの坐剤を使用したヒトでの報告はな い。Y Yamamotoら 5) は, 人為的に甲状腺機能低下をきた したウサギはレボチロキシン坐剤投与 3.5 時間以内に血 清 T4濃度が上昇し, 48 時間以上高值が持続したことを 報告している。本症例では, 坐剤投与は同量の経胃管 投与に比して, 短時間で意識が改善し, 改善していた時 間も長かったため, 坐剤投与後の速やかかつ確実な吸 収が示唆された。

本症例の反省点として, 甲状腺ホルモンの初期投与 量 $(12.5 \mu \mathrm{g} / \mathrm{day})$ が少な過ぎた可能性は否めない。 T4 の甲状腺外プールは約 $360 \mu \mathrm{g}$ 存在し, 粘液水腫性昏睡 においてはこのプールが枯渴していると考えられてい る5)。この枯渇分を補充するために, T4製剤で300〜 $500 \mu \mathrm{g} /$ day 初期大量投与を行った後に維持量を投与 することを推奨する文献も散見される6),7)。一方, 粘液 水腫性昏睡に対する長期少量投与の有効性も示唆され ており 8), 今回我々は患者が高齢であることを考慮し, 少量のレボチロキシン投与から開始した。

\section{結 語}

レボチロキシン坐剂が有効であった粘液水腫性昏睡 の1例を経験した。腸管蠕動運動低下や内服薬の生物 学的利用能を考慮すると, 坐剂による甲状腺ホルモン 製剂の投与も検討の価值があることが示唆された。

本論文の要旨は, 第21回日本集中治療医学会関東甲信越 地方会 $(2012$ 年, 前橋)において発表した。

本稿の全ての著者には規定されたCOIはない。

\section{文 献}

1) Kwaku MP, Burman KD. Myxedema coma. J Intensive Care Med 2007;22:224-31.

2) 小西美絵乃, 盛田幸司, 田中祐司. IV. 難治性甲状腺疾患 3. 粘液水腫性昏睡. 日内会誌 2010;99:769-75.

3) 日本病院薬剤師会編. 病院薬局製剂 第 5 版. 東京 : 薬事日 報社；2003. p. 209 .

4) Hays MT. Absorption of oral thyroxine in man. J Clin Endocrinol Metab 1968;28:749-56.

5) Yamamoto M, Yonezawa K, Mizugaki M, et al. Replacement of L-T4 suppository in MMI treated rabbits. Endocrinol Jpn 1990;37:355-9.

6) Holvey DN, Goodner CJ, Nicoloff JT, et al. Treatment of myxedema coma with intravenous thyroxine. Arch Intern Med 1964;113:89-96.

7) Forester CF. Coma in myxedema. Report of a case and review of the world literature. Arch Intern Med 1963;111:734-43.

8) 藤吉 朗, 山本智英. 少量からの甲状腺ホルモン補充にて 治療し得た粘液水腫昏睡の 2 症例. 日救急医会誌 2000;11:22-6. 